\title{
Polyethylene glycol damages grafted citrus plants based on biometric, physiological, and biochemical responses
}

\author{
Eduardo Augusto Girardi ${ }^{1}$, Andréa Dias Brandão ${ }^{2}$, Rubens Duarte Coelho ${ }^{3}$, \\ Hilton Thadeu Zarate do Couto ${ }^{3}$, Marcos Silveira Buckeridge ${ }^{4}$, Francisco de Assis Alves Mourão Filho ${ }^{3}$ \\ Abstract - Drought tolerance is a major trait for the selection of citrus rootstocks in breeding \\ programs. PEG 4000 solution at $110 \mathrm{~g} \mathrm{~L}^{-1}$ (osmotic potential of $-376 \mathrm{kPa}$ ) was used to evaluate \\ biometric, physiological, and biochemical responses of grafted citrus plants in pots. 'Valencia' \\ sweet orange plants grafted onto 'Rangpur' lime (drought tolerant) rootstock showed greater \\ plant growth compared to that on 'Swingle' citrumelo (drought sensitive) rootstock, regardless \\ of PEG-induced stress; however, biological responses to PEG were similar on both rootstocks. \\ Plant dry weight, gas exchange, and leaf and root starch concentrations were reduced by PEG. \\ Water potential at 2:00 p.m. and $\mathrm{Fe}$ and $\mathrm{Mn}$ leaf concentrations increased with severe phytotoxic \\ symptoms. The results corroborate the limitation of PEG for assessing drought tolerance of citrus \\ plants at the whole plant level. \\ Index terms: Citrus limonia, Citrus paradisi $x$ Poncirus trifoliata, osmotic agent, rootstock, \\ water deficit.

\section{Polietileno glicol prejudica plantas enxertadas de citros com base em respostas biométricas, fisiológicas e bioquímicas}

Corresponding author: francisco.mourao@usp.br

Received: June 19, 2018 Accepted: September 05, 2018.

Copyright: All the contents of this journal, except where otherwise noted, is licensed under a Creative Commons Attribution License.
Resumo - A tolerância à seca é um dos principais atributos para a seleção de porta-enxertos de citros em programas de melhoramento genético. Solução de PEG 4.000 a $110 \mathrm{~g} \mathrm{~L}^{-1}$ (potencial osmótico de $-376 \mathrm{kPa}$ ) foi aplicada para avaliar respostas biométricas, fisiológicas e bioquímicas de plantas enxertadas de citros em recipientes. Laranja 'Valencia' enxertada em limão 'Cravo' (tolerante à seca) apresentou maior crescimento vegetativo do que sobre citrumelo 'Swingle' (intolerante à seca), independentemente do estresse por PEG. Contudo, as respostas biológicas ao agente osmótico foram similares para ambos os porta-enxertos. Matéria seca, trocas gasosas e concentração de amido em folhas e raízes foram reduzidas pela aplicação de PEG. Potencial hídrico às $14 \mathrm{~h}$ e concentrações foliares de Fe e Mn aumentaram com sintomas severos de fitotoxicidade. Esses resultados corroboram a limitação de PEG para avaliar a tolerância à seca de citros em plantas inteiras.

Termos para indexação: Citrus limonia, Citrus paradisi $x$ Poncirus trifoliata, agente osmótico, deficiência hídrica, porta-enxerto. 
Citrus trees are cultivated in regions subjected to seasonal drought that constrains fruit yield under rainfed cultivation or in irrigated orchards with limited water supply (CARR, 2012). Drought tolerance is a major trait for rootstock breeding and selection (CASTLE, 2010), and each scion-rootstock combination may show several distinct biological responses under water deficit (RIBEIRO et al., 2014).

Osmotic agents, such as polyethylene glycol (PEG), are commonly added to the soil or potting mix to assess drought tolerance in potted plants, since field experiments are more costly, time-consuming and involve exposure to other abiotic and biotic stresses (COMEAU et al., 2010; PENELLA et al., 2014). A given soil osmotic potential can be indefinitely set with the use of PEG, which cannot be reproduced by other water deficit-inducing methods.

Drought tolerance in citrus plants has been evaluated with PEG as an osmotic stress agent in hydroponic and in vitro cultures, and in potted seedlings of different species (ZEKRI; PARSONS, 1990; ZEKRI, 1991, 1993; MADEMBA-SY et al., 2003; BOSCARIOLCAMARGO et al., 2007; FORNER-GINER et al., 2011). PEG solutions with molecular weights from 4000 to 6000 have been extensively used, in spite of their welldocumented detrimental effects and phytotoxic effects (PLAUT; FEDERMAN, 1985). The putative influence of the citrus scion-rootstock combination on responses to PEG has not yet been described, although it was demonstrated in other crops (PENELLA et al., 2014).

In this study, the hypothesis that polyethylene glycol (PEG) solution can be applied on grafted citrus plants as a method for selecting drought resistant rootstocks was tested.

This study was carried out in a screen-protected commercial citrus nursery in Araras, state of São Paulo, Brazil (22 $25^{\circ} 15^{\prime} \mathrm{S}, 47^{\circ} 23^{\prime} 03^{\prime}$ W, $\left.611 \mathrm{~m}\right)$. Daily maximum and minimum average air temperatures were $40.5^{\circ} \mathrm{C}$ and $18.6^{\circ} \mathrm{C}$, respectively, and average relative humidity was $70 \%$ during the assessment period.

'Valencia' sweet orange (VO) [Citrus sinensis (L.) Osbeck] plants were budded onto 'Rangpur' lime (RL) $(C$. limonia Osbeck) or 'Swingle' citrumelo (SC) [C. paradisi cv. Duncan Macf. X Poncirus trifoliata (L.) Raf.]. These rootstocks are considered more tolerant and less tolerant to drought stress, respectively (RIBEIRO et al., 2014).

Eight-month-old nucellar RL or SC seedlings cultivated in 4.5-L polyethylene bags filled with commercial pine bark potting mix (Rendmax ${ }^{\mathrm{TM}}$ Citrus) were grafted with VO buds at $15-\mathrm{cm}$ height in December 2006. Cultural practices usually recommended for container-grown citrus nursery plants were followed (CARVALHO et al., 2005) and, upon grafting, a controlled-release fertilizer (22-04-08) $\left(\right.$ Osmocote $\left.^{\mathrm{TM}}\right)$ was applied at $11 \mathrm{~g} \mathrm{plant}^{-1}$.

PEG-induced stress was initiated after unwrapping of the budding tape with the application of PEG 4000 (Oxiteno Sibol Ltda.) at $110 \mathrm{~g} \mathrm{~L}^{-1}$, which corresponds to solution with -376 kPa osmotic potential (ZEKRI, 1991). Each plant was daily irrigated with $300 \mathrm{~mL}$ of this solution from 15 to 120 days after grafting (DAG). Control plants were irrigated with the same volume of tap water that maintained the container moisture at field capacity. The $\mathrm{pH}$ of the potting mix was also weekly monitored by testing the leaching solution.

The experiment was installed in a $2 \times 2$ factorial design (rootstocks $\times$ PEG levels) with five replicates and three grafted plants per plot. A preliminary evaluation was conducted with different osmotic concentrations and periods of PEG application, and the combination of $-376 \mathrm{kPa}$ and $15-120 \mathrm{DAG}$ was selected as the most representative to be used in this study.

Leaf and root dry weights were measured at 120 DAG. Samples (all leaves harvested form each plant and the entire root system per plant including the taproot) were dried at $65{ }^{\circ} \mathrm{C}$ for $72 \mathrm{~h}$. The water potential was measured at $120 \mathrm{DAG}$ at 6:00 a.m. and 2:00 p.m. in a pressure chamber (model 3005, Soil Moisture Equipment Co.), using mature fully-expanded leaves from the apex. Gas exchange was measured on the same type of leaves at $120 \mathrm{DAG}$, with infrared gas analyser (LI-6400, LiCor Inc.) adjusted to $1000 \mu \mathrm{mol}$ photons $\mathrm{m}^{-2} \mathrm{~s}^{-1}$, air flow of $450 \mu \mathrm{mol} \mathrm{s}^{-1}$ and ambient relative air humidity and $\mathrm{CO}_{2}$ concentration. During assessments, average air temperature in the greenhouse was about $23{ }^{\circ} \mathrm{C}$, vapour pressure deficit of approximately $1.75 \mathrm{kPa}$, and PAR $\approx$ $150 \mu \mathrm{mol}$ photons $\mathrm{m}^{-2} \mathrm{~s}^{-1}$.

Leaf nutrient $\mathrm{N}, \mathrm{P}, \mathrm{K}, \mathrm{Ca}, \mathrm{Mg}, \mathrm{B}, \mathrm{Cu}, \mathrm{Fe}, \mathrm{Mn}$ and $\mathrm{Zn}$ concentrations were determined at $120 \mathrm{DAG}$ (samples comprised six mature leaves per plant, 18 leaves per plot, and three replicates) according to standard analysis (SRIVASTAVA, 2012). Starch concentrations were determined at 120 DAG according to Amaral et al. (2007) in three replicates, with plants separated into root system and leaves. As described for dry weight, samples were dried at $80^{\circ} \mathrm{C}$ for $72 \mathrm{~h}$, ground and sieved $(0.8 \mathrm{~mm}$ mesh); 30 and $50 \mathrm{mg}$ of dried leaf and root samples, respectively, were separated from the total material obtained per replicate.

Data were submitted to analyses of variance $(P$ $\leq 0.05$ ) and results presented as relative percentages to facilitate comparison of variables within the same figure, with RL control plants as $100 \%$. Original data on leaf nutrient concentrations were presented for the main rootstock effect.

Leaf and root dry weights were higher for $\mathrm{VO} / \mathrm{RL}$ regardless of treatment, approximately 2.25- and 1.33-fold higher, respectively. In contrast, there was approximately $55 \%$ and $33 \%$ reduction in leaf and root dry weights, respectively, with PEG application with both rootstocks (Figure $1 \mathrm{~A}$ and $\mathrm{B}$ ).

Leaf water potential at 6:00 a.m. (predawn) was reduced by approximately $33 \%$ by PEG with both rootstocks (Figure $1 \mathrm{C}$ ). Conversely, at 2:00 p.m., PEG application resulted in water potential $33 \%$ higher (Figure 
$1 \mathrm{D})$. SC and RL were more sensitive to PEG-stress at 6:00 a.m. and 2:00 p.m., respectively. Gas exchange variables showed response similar to PEG; only the net $\mathrm{CO}_{2}$ assimilation rate $(A)$ is presented (Figure $1 \mathrm{E}$ ). PEG drastically reduced $A$, notably in plants with RL rootstock $(-80 \%)$.

SC led to higher leaf $\mathrm{N}, \mathrm{P}, \mathrm{Ca}, \mathrm{Mg}$ and $\mathrm{B}$ concentrations, whereas RL resulted in higher $\mathrm{Fe}, \mathrm{Cu}$, $\mathrm{Mn}$ and $\mathrm{Zn}$ concentrations in $\mathrm{VO}$ leaves regardless of treatment (Table 1). Leaf mineral composition varied according to the duration and intensity of PEG-induced stress (data not shown); consistent results were observed only for Fe and $\mathrm{Mn}$, which were increased by $28 \%$, on average, with both rootstocks (Figure $1 \mathrm{~F}$ and $\mathrm{G}$ ).

Starch concentration was higher in the leaves and roots of control VO/RL (Figures $1 \mathrm{H}$ and I). PEG-stress decreased the starch concentration in leaves by $75 \%$ and $40 \%$ with RL and SC, respectively, in relation to control. In contrast, starch depletion in the roots was similar for both rootstocks (approximately 30\%). This decrease in starch concentration within plant organs was related to the reduced $A$, resulting in depletion of this energy reservoir under PEG stress (Figure $1 \mathrm{E}$ ).

PEG-stressed plants showed phytotoxic effects, regardless of rootstock used (Figure 2). Initially, there was mild internerval leaf chlorosis, similar to Mn deficiency, with no change in leaf size or shape (Figure $2 \mathrm{~A}$ ). These symptoms developed into severe chlorosis, which began to fold over the ventral side (mild curling) (Figure 2 B). With the progress of PEG application, leaves became heavily deformed, with severe curling towards the ventral side and a large reduction in blade area, including margin necrosis, and leaf abscission (Figure $2 \mathrm{C}$ and $\mathrm{D}$ ). The apex was more damaged and vegetative growth was continuous, making it difficult to distinguish different shoot flushes. Towards the end of assessments, water irrigation was restored and new shoots were visually healthy (Figure 2 E). Non-stressed plants were symptomless throughout the evaluation.

The high growth and starch content of plants with $\mathrm{RL}$ rootstocks, especially the root system even under severe stress caused by PEG, corroborated studies on potted plants under water deficit (PEDROSO et al., 2014). Plants grafted onto RL usually acclimate to drought stress in a faster way and benefit from a more efficient carbohydrate partitioning induced by this rootstock. However, the relative biological responses to PEG stress observed in this study were very similar between plants grafted onto RL and SC, although being well-known drought tolerant and sensitive rootstocks, respectively, in both field and greenhouse conditions (PEDROSO et al., 2014; RIBEIRO et al., 2014). Therefore, there was no clear association between drought tolerance of evaluated rootstocks and PEG-induced stress.

PEG application at $-376 \mathrm{kPa}$ clearly led to detrimental effects on grafted citrus plants by decreasing plant growth, gas exchange and starch concentrations in leaves and roots. The same sharp decline was observed in 'Cleopatra' mandarin (C. reshni Hort ex Tanaka), sour orange (C. aurantium L.), P. trifoliata and 'Carrizo' citrange rootstock seedlings $(C$. sinensis $\times P$. trifoliata $)$ in pots irrigated with PEG solutions (ZEKRI; PARSONS, 1990; ZEKRI, 1991, 1993; FORNER-GINER et al., 2011). The higher leaf water potential of PEG-stressed plants at 2:00 p.m. in relation to the control also suggests a different physiological mechanism in response to water deficit.

Phytotoxic effects in grafted citrus plants observed in this work are similar to those described for seedlings of several citrus species by ZEKRI (1991, 1993), who proposed that the phytotoxic effects of PEG in citrus plants arise from the higher $\mathrm{Mn}$ and $\mathrm{Zn}$ accumulation in the roots and leaves. In the present study, the potting mix in control and PEG-stressed plants had $\mathrm{pH}$ values of approximately 6.3 and 4.5 , respectively, throughout evaluation. As $\mathrm{pH}$ interferes in the absorption and accumulation of cationic micronutrients (KUMIKO; TORU, 2004), the effect of PEG elevating the acidity may have favoured $\mathrm{Fe}$ and $\mathrm{Mn}$ imbalance and phytotoxic effects (Figure $1 \mathrm{~F}$ and $\mathrm{G}$; Figure 2). PEG is also considered an efficient adsorptive substance for $\mathrm{Fe}$ and $\mathrm{Mn}$ ions in aqueous solutions, with higher adsorption capacity at $\mathrm{pH}$ range of $2.9-5.9$ (REIAD et al., 2012).

The observed phytotoxic symptoms and physiological effects are not expected to be directly caused by the low $\mathrm{pH}$ induced by PEG application, since the physiological apparatus of different citrus rootstocks were not affected by $\mathrm{pH}$ values as low as 4.0 in nutritive solutions without Al (PEREIRA et al., 2000). On the other hand, 'Volkamer' lemon (C. volkameriana Ten. \& Pasq.) seedlings showed reduction in photosynthetic efficiency when Mn concentrations in leaves were high (PAPADAKIS et al., 2007), which was similar to PEG application results obtained in the present study.

In conclusion, the initial hypothesis of this study, "feasibility of the use of polyethylene glycol (PEG) solution in grafted citrus plants as a method for selecting drought resistant rootstocks", was rejected by the results obtained in this experiment. 'Valencia' sweet orange grafted onto 'Rangpur' lime (drought tolerant) rootstock was more vigorous than with 'Swingle' citrumelo (drought sensitive) rootstock, regardless of PEG-induced stress. PEG solution causes phytotoxic symptoms and detrimental plant performance in grafted citrus plants, irrespective of the drought tolerant properties of the rootstock variety. PEG-induced toxic stress and water deficit stress occurred at the same time in citrus plants, and it was not possible to separately quantify these effects. 
Table 1. Leaf nitrogen $(\mathrm{N})$, phosphorus $(\mathrm{P})$, potassium $(\mathrm{K})$, calcium $(\mathrm{Ca})$, magnesium $(\mathrm{Mg})$, boron $(\mathrm{B})$, copper $(\mathrm{Cu})$, iron (Fe), manganese ( $\mathrm{Mn})$ and zinc $(\mathrm{Zn})$ concentrations in 'Valencia' sweet orange grafted onto 'Rangpur' lime (RL) and 'Swingle' citrumelo (SC) rootstocks, grown in pots and irrigated with polyethylene glycol (PEG) at $-376 \mathrm{kPa}$ from 15 to 120 days after grafting.

\begin{tabular}{lcccccccccc}
\hline Rootstock & $\mathrm{N}$ & $\mathrm{P}$ & $\mathrm{K}$ & $\mathrm{Ca}$ & $\mathrm{Mg}$ & $\mathrm{B}$ & $\mathrm{Cu}$ & $\mathrm{Fe}$ & $\mathrm{Mn}$ & $\mathrm{Zn}$ \\
& ----------------- & $\left(\mathrm{g} \mathrm{kg}^{-1}\right)$ & $-----9 \mathrm{~b}$ & $2.89 \mathrm{~b}$ & $46.9 \mathrm{~b}$ & $123 \mathrm{a}$ & $108 \mathrm{a}$ & $107 \mathrm{a}$ & $37.2 \mathrm{a}$ \\
\hline $\mathrm{RL}$ & $27.4 \mathrm{~b}$ & $1.39 \mathrm{~b}$ & $21.2 \mathrm{a}$ & $24.9 \mathrm{~b}$ & & \\
$\mathrm{SC}$ & $31.3 \mathrm{a}$ & $1.58 \mathrm{a}$ & $21.5 \mathrm{a}$ & $26.6 \mathrm{a}$ & $3.91 \mathrm{a}$ & $53.4 \mathrm{a}$ & $83 \mathrm{~b}$ & $103 \mathrm{~b}$ & $82 \mathrm{~b}$ & $33.1 \mathrm{~b}$ \\
\hline $\mathrm{CV} \%$ & 4.2 & 6.2 & 6.0 & 5.2 & 6.6 & 7.3 & 10.0 & 8.8 & 9.1 & 11.8 \\
\hline
\end{tabular}

*Mean values followed by the same letters are equivalent by the $\mathrm{F}$-test $(\mathrm{P} \leq 0.05)$.
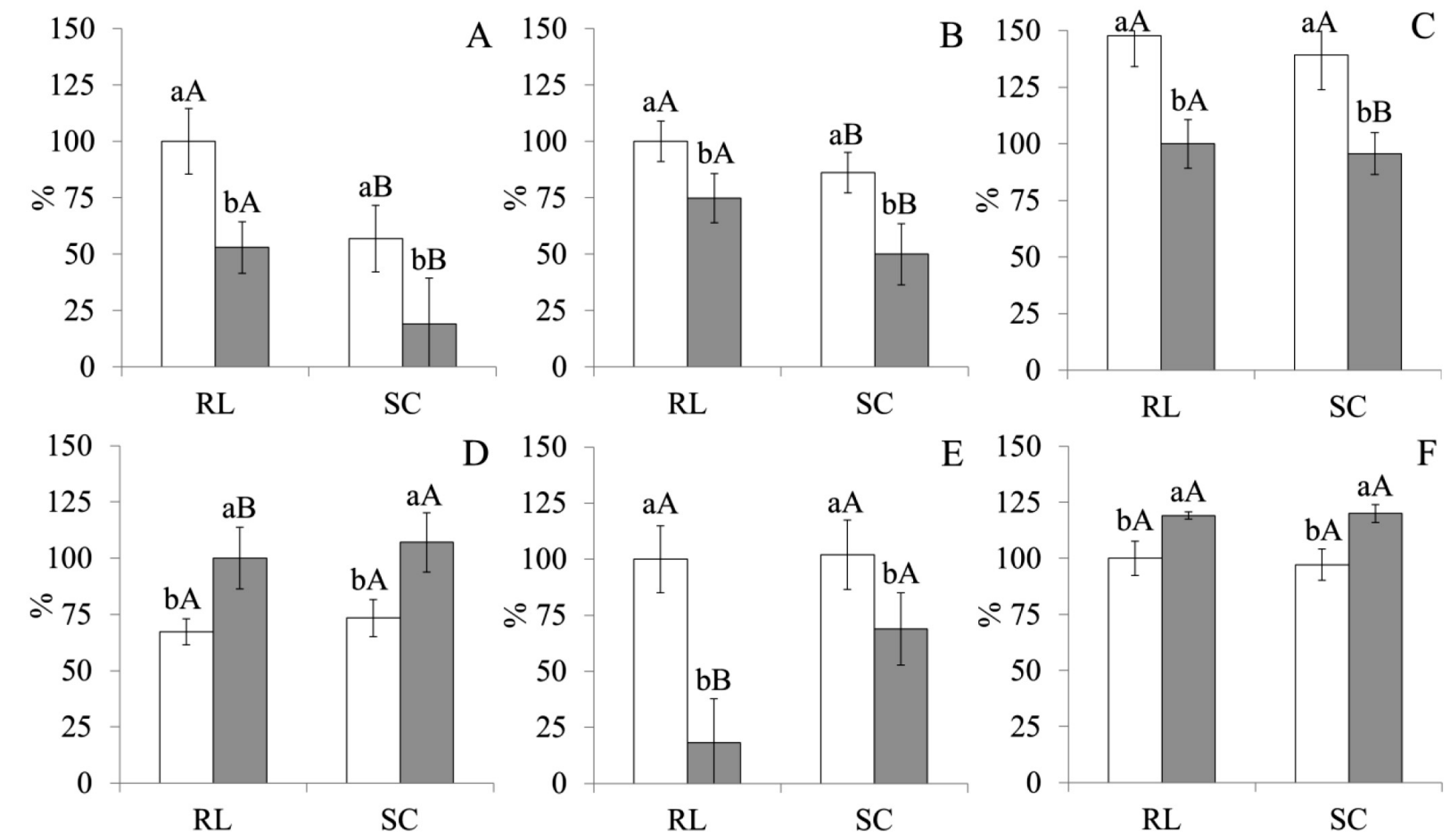

D 150

RL

E 150

RL

$\mathrm{SC}$
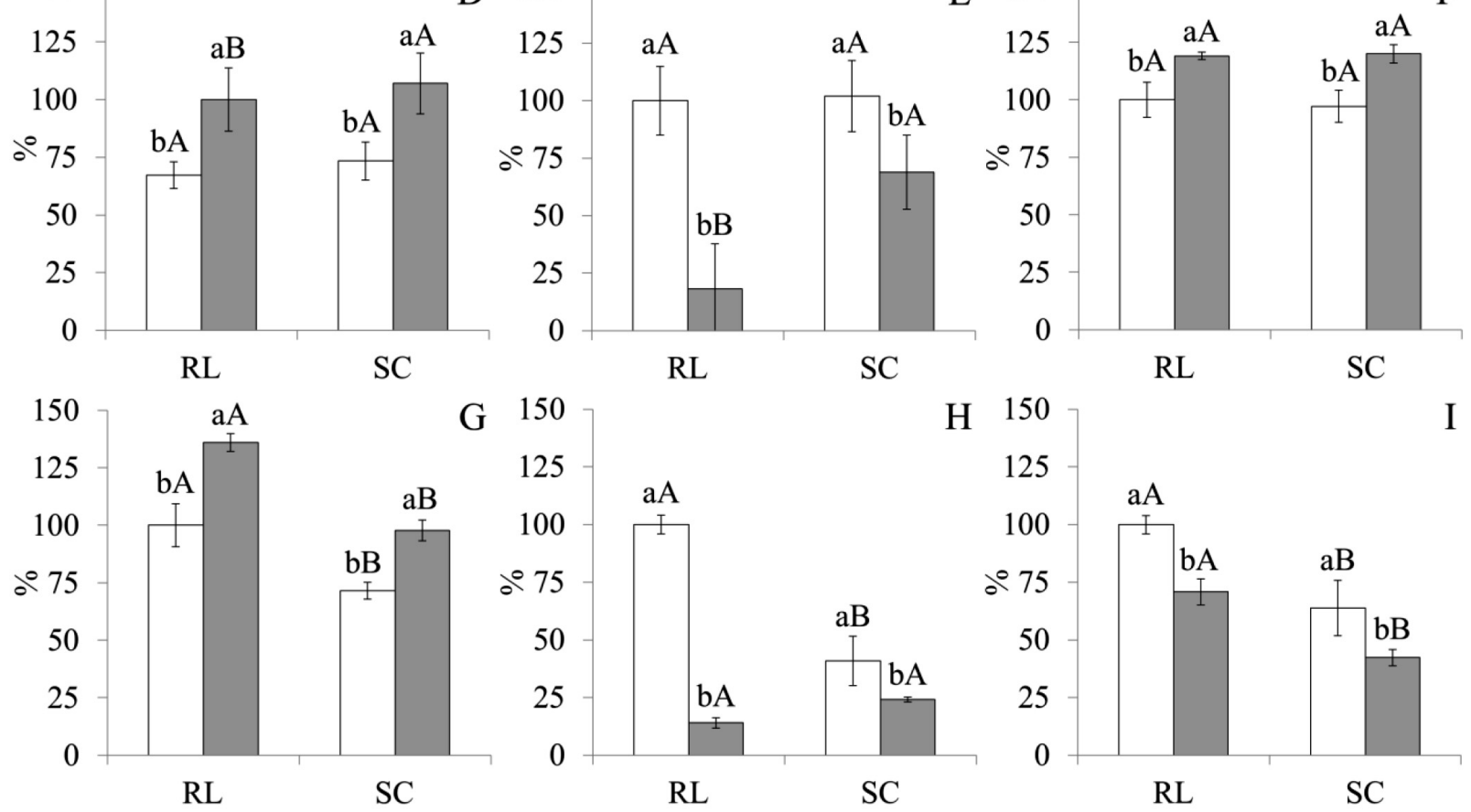

\section{$\square \mathrm{CC} \quad \square \mathrm{PEG}$}

Figure 1. Relative mean values (\%) of leaf (A) and root (B) dry weights, leaf water potential at 6:00 a.m. (C) and 2:00 p.m. (D), net $\mathrm{CO}_{2}$ assimilation rate (E), leaf Fe (F) and Mn concentrations (G), and leaf (H) and root (I) starch concentrations of 'Valencia' sweet orange (VO) grafted onto 'Rangpur' lime (RL) and 'Swingle' citrumelo (SC) rootstocks in pots, and irrigated with polyethylene glycol (PEG) at $-376 \mathrm{kPa}$ from 15 to 120 days after grafting. $\mathrm{CC}=$ plants daily irrigated at container capacity (control). Relative mean values \pm relative standard errors followed by the same lowercase and capital letters, respectively, between treatments within each rootstock and between rootstocks within each treatment, are not different by the F-test $(\mathrm{P} \leq 0.05)$. 


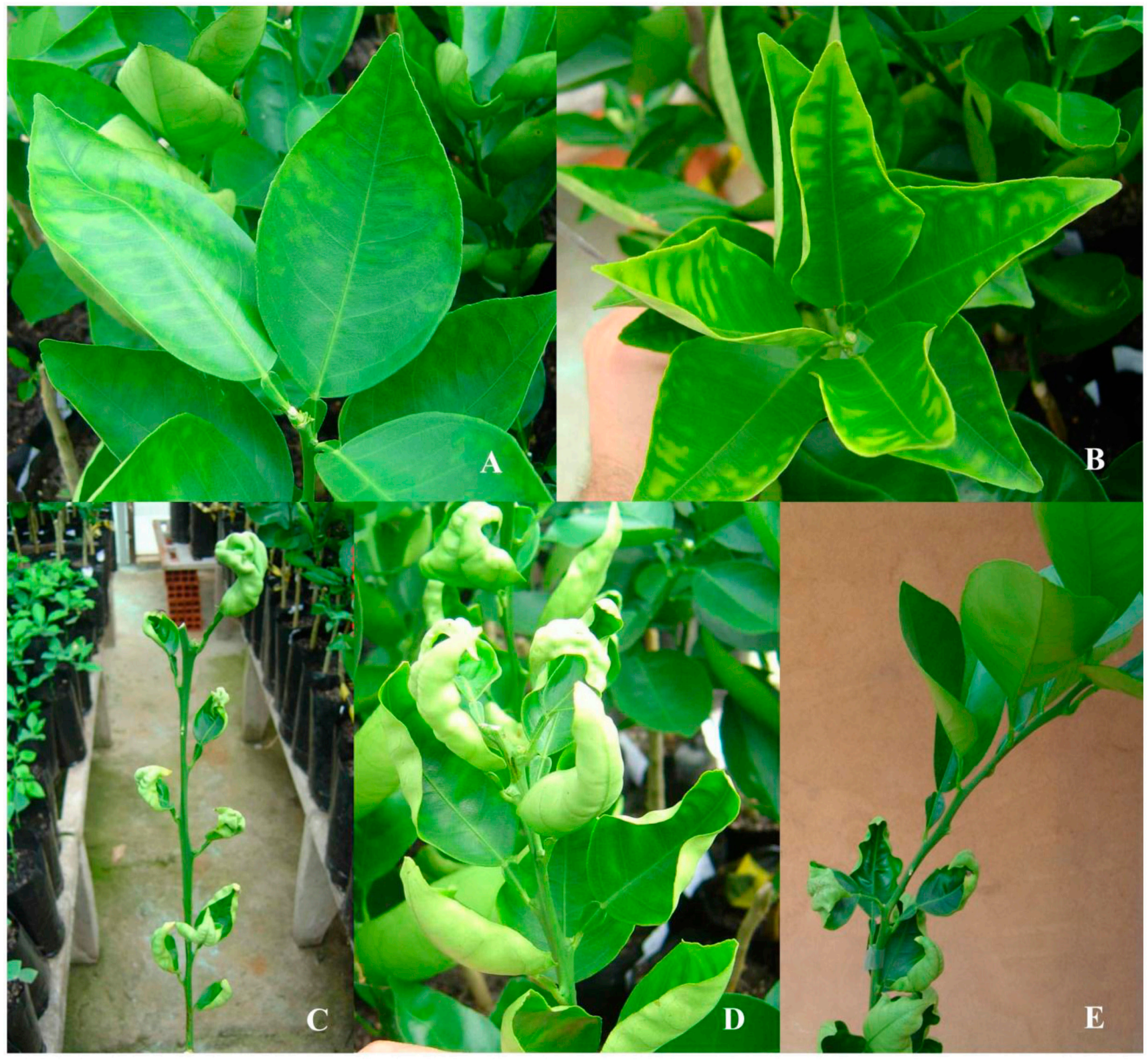

Photographs: E. A. Girardi

Figure 2. Initial symptoms of phytotoxic effects in grafted citrus plants irrigated with polyethylene glycol (PEG) solution (A and B); advanced phytotoxic symptoms in grafted citrus plants irrigated with PEG solution at $-376 \mathrm{kPa}$ (C and D); healthy aspect of new shoot flush after restoring regular water irrigation without PEG solution (E). 


\section{Acknowledgements}

To the São Paulo Research Foundation (FAPESP) for granting the doctorate scholarship to the first author (Process 2006/01470-7) and for financial support (Process 2006/01469-9), to the Coordination of Improvement of Higher Level Personnel (Coordenação de Aperfeiçoamento de Pessoal de Nível Superior, Brazil - CAPES) for partial financial aid (Finance Code 001), and to SaniCitrus Nursery for the technical support for this study. In addition, we thank Dr. Lilian Amorin, Dr. Carlos Guilherme Silveira Pedreira, and Dr. Ricardo Ferraz de Oliveira (University of São Paulo) for the use of equipment.

\section{References}

AMARAL, L. I. V.; GASPAR, M.; COSTA, P. M. F.; AIDAR, M. P. M.; BUCKERIDGE, M. S. Novo método enzimático e sensível de extração e dosagem de amido em materiais vegetais. Hoehnea, São Paulo, v.34, n.4, p.425-431, 2007.

BOSCARIOL-CAMARGO, R. L.; BERGER, I. J.; SOUZA, A. A.; AMARAL, A. M.; CARLOS, E. F.; FREITAS-ASTÚA, J.; TAKITA, M. A.; TARGON, M. L. P. N.; MEDINA, C. L.; REIS, M. S.; MACHADO, M. A. In silico analysis of ESTs from roots of Rangpur lime (Citrus limonia Osbeck) under water stress. Genetics and Molecular Biology, Ribeirão Preto, v.30, n.3, p.906-916, 2007.

CARR, M. K. V. The water relations and irrigation requirements of citrus (Citrus spp): a review. Experimental Agriculture, Cambridge, v.48, n.3, p.347-377, 2012.

CARVALHO, S. A.; GRAF, C. C. D.; VIOLANTE, A. R. Produção de material básico e propagação. In: MATTOS JUNIOR, D.; NEGRI, J. D.; PIO, R. M.; POMPEU JUNIOR, P. Citros. Campinas: Instituto Agronômico de Campinas; Fundag, 2005. p. 281-316.

CASTLE, W.S. A career perspective on citrus rootstocks, their development, and commercialization. HortScience, Alexandria, v.45, n.1, p.11-15, 2010.

COMEAU, A.; NODICHAO, L.; COLLIN, J.; BAUM, M.; SAMSATLY, J.; HAMIDOU, D.; LANGEVIN, F.; LAROCHE, A.; PICARD, E. New approaches for the study of osmotic stress induced by polyethylene glycol (PEG) in cereal species. Cereal Research Communications, Budapest, v.38, n.4, p.471-481, 2010.
FORNER-GINER, M.A.; RODRIGUEZ-GAMIR, J.; PRIMO-MILLO, E.; IGLESIAS, D.J. Hydraulic and chemical responses of citrus seedlings to drought and osmotic stress. Journal of Plant Growth Regulation, New York, v.30, n.3, p.353-366, 2011.

KUMIKO, O.; TORU, M. Alleviation of salinity damage to rice plants by the use of polyethylene glycols (PEGs) through reduction of $\mathrm{Na}+$ transport to shoots. Soil Science and Plant Nutrition, Tokyo, v.50, n.1, p.129-133, 2004.

MADEMBA-SY, F.; BOUCHEREAU, A.; LARHER, F.R. Proline accumulation in cultivated citrus and its relationship with salt tolerance. The Journal of Horticultural Science and Biotechnology, London, v.78, n.5, p.617-623, 2003.

PAPADAKIS, I.E.; GIANNAKOULA, A.; ANTONOPOULOU, C.P.; MOUSTAKAS, M.; AVRAMAKI, E.; THERIOS, I.N. Photosystem 2 activity of Citrus volkameriana (L.) leaves as affected by $\mathrm{Mn}$ nutrition and irradiance. Photosynthetica, Dordrecht, v.45, n.2, p.208-213, 2007.

PEDROSO, F.K.J.V.; PRUDENTE, D.A.; BUENO, A.C.R.; MACHADO, E.C.; RIBEIRO, R.V. Drought tolerance in citrus trees is enhanced by rootstockdependent changes in root growth and carbohydrate availability. Environmental and Experimental Botany, Amsterdam, v.101, p.26-35, 2014.

PENELLA, C.; NEBAUER, S.G.; BAUTISTA, A.S.; LÓPEZ-GALARZA, S.; CALATAYUD, Á. Rootstock alleviates PEG-induced water stress in grafted pepper seedlings: physiological responses. Journal of Plant Physiology, Jena, v.171, n.10, p.842-851, 2014.

PEREIRA, W.E.; SIQUEIRA, D.L.; MARTÍNEZ, C.A.; PUIATTI, M. Gas exchange and chlorophyll fluorescence in four citrus rootstocks under aluminium stress. Journal of Plant Physiology, Jena, v.157, n.5, p.513-520, 2000.

PLAUT, Z.; FEDERMAN, E. A simple procedure to overcome polyethelene glycol toxicity on whole plants. Plant Physiology, Rockville, v.79, p.559-561, 1985.

REIAD, N.A.; ABDEL SALAM, O.E.; ABADIR, E.F.; FARID, A.H. Adsorptive removal of iron and manganese ions from aqueous solutions with microporous chitosan/ polyethylene glycol blend membrane. Journal of Environmental Sciences, Amsterdam, v.24, n.8, p.14251432, 2012. 
RIBEIRO, R.V.; ESPINOZA-NUÑEZ, E.; POMPEU JUNIOR, J.; MOURÃO FILHO, F.A.A.; MACHADO, E.C. Citrus rootstocks for improving the horticultural performance and physiological responses under constraining environments. In: AHMAD, P. (Ed.). Improvement of crops in the era of climatic changes. New York: Springer Science+Business Media, 2014. p.1-37.

SRIVASTAVA, A.K. Advances in citrus nutrition. New York: Springer Science+Business Media, 2012. 473p.

ZEKRI, M. Effects of PEG-induced water-stress on two citrus cultivars. Journal of Plant Nutrition, Philadelphia, v.14, n.1, p.59-74, 1991.
ZEKRI, M. Osmotic and toxic ion effects on seedling emergence and nutrition of citrus rootstocks. Journal of Plant Nutrition, Philadelphia, v.16, n.10, p.2013-2028, 1993.

ZEKRI, M., PARSONS, L.R. Comparative effects of $\mathrm{NaCl}$ and polyethylene-glycol on root distribution, growth, and stomatal conductance of sour orange seedlings. Plant and Soil, Dordrecht, v.129, n.2, p.137-143, 1990. 